\title{
Autocrine Activation of Neuronal NMDA Receptors by Aspartate Mediates Dopamine- and cAMP-Induced CREB-Dependent Gene Transcription
}

\author{
Luis E. F. Almeida, ${ }^{1}$ Peter D. Murray, ${ }^{1,5}$ H. Ronald Zielke, ${ }^{2}$ Clinton D. Roby, ${ }^{1}$ Tami J. Kingsbury, ${ }^{1,4,5}$ \\ and Bruce K. Krueger ${ }^{1,3,5}$ \\ Departments of ${ }^{1}$ Physiology, ${ }^{2}$ Pediatrics, and ${ }^{3}$ Psychiatry, ${ }^{4}$ Program in Oncology, Marlene and Stewart Greenebaum Cancer Center, University of Maryland \\ School of Medicine, and ${ }^{5}$ Program in Neuroscience, University of Maryland Baltimore, Baltimore, Maryland 21201
}

cAMP can stimulate the transcription of many activity-dependent genes via activation of the transcription factor, cAMP response element-binding protein (CREB). However, in mouse cortical neuron cultures, prior to synaptogenesis, neither cAMP nor dopamine, which acts via cAMP, stimulated CREB-dependent gene transcription when NR2B-containing NMDA receptors (NMDARs) were blocked. Stimulation of transcription by cAMP was potentiated by inhibitors of excitatory amino acid uptake, suggesting a role for extracellular glutamate or aspartate in cAMP-induced transcription. Aspartate was identified as the extracellular messenger: enzymatic scavenging of L-aspartate, but not glutamate, blocked stimulation of CREB-dependent gene transcription by cAMP; moreover, cAMP induced aspartate but not glutamate release. Together, these results suggest that cAMP acts via an autocrine or paracrine pathway to release aspartate, which activates NR2B-containing NMDARs, leading to $\mathrm{Ca}^{2+}$ entry and activation of transcription. This cAMP/aspartate/NMDAR signaling pathway may mediate the effects of transmitters such as dopamine on axon growth and synaptogenesis in developing neurons or on synaptic plasticity in mature neural networks.

\section{Introduction}

cAMP is a ubiquitous intracellular second messenger that regulates a wide range of cellular processes in the nervous system throughout the vertebrate lifespan, including synaptogenesis, growth of axons, dendrites and dendritic spines, and persistent changes in synaptic plasticity such as long-term potentiation (LTP) (Nguyen and Kandel, 1996; Boulanger and Poo, 1999; Ma et al., 1999; Cai et al., 2001; Kao et al., 2002; Tominaga-Yoshino et al., 2002; Nguyen and Woo, 2003; Otmakhov et al., 2004; Ji et al., 2005; Wozny et al., 2008). Neuronal levels of cAMP are regulated by G-protein-coupled receptors linked to adenylyl cyclase (AC). In the cortex, hippocampus and striatum, the neurotransmitter, dopamine (DA), activates AC via D1/D5 DA receptors to regulate neuronal growth and differentiation during development (Schmidt et al., 1998; Jones et al., 2000) and synaptic plasticity and cognitive function in the mature brain (Huang and

Received March 10, 2009; revised Aug. 6, 2009; accepted Sept. 2, 2009.

Funding was provided by National Institutes of Health (NIH) Grant R01NS048095 and Department of Defense Contract W81XWH-04-1-0176 (B.K.K.), by NIH Grant HD16596 (H.R.Z.), and by NIH Training Grants T32DE007309 (L.E.F.A.), T32NS07375 (T.J.K.), and T32GM08181 (P.D.M.). T.J.K. was a BIRCWH (Building Interdisciplinary Research Careers in Women's Health) Scholar supported by National Institute of Child Health and Human Development-Office of Research on Women's Health-National Institute of Diabetes and Digestive and Kidney Diseases (NICHD/ORWH/ NIDDK) Grant K12HD43489. We gratefully acknowledge Drs. T. W. Abrams and B. E. Alger (University of Maryland School of Medicine, Baltimore, MD) and Dr. D. D. Ginty (Johns Hopkins University School of Medicine, Baltimore, MD) for comments on this manuscript.

Correspondence should be addressed to Bruce K. Krueger, Department of Physiology, University of Maryland School of Medicine, 655 West Baltimore Street, Baltimore, MD 21201. E-mail: bkrueger@umaryland.edu.

DOI:10.1523/JNEUROSCI.1166-09.2009

Copyright $\odot 2009$ Society for Neuroscience ～0270-6474/09/2912702-09\$15.00/0
Kandel, 1995; Otmakhova and Lisman, 1998; Bach et al., 1999; Huang et al., 2004; Shen et al., 2008).

cAMP activates cAMP-dependent protein kinase (PKA), which can directly modulate effector proteins by phosphorylation at PKA-specific serine or threonine residues or can alter the levels of the effector proteins themselves by modulating gene expression. Promoters containing $\mathrm{CAMP} / \mathrm{Ca}^{2+}$-response elements (CREs) are regulated by the transcription factor, CREbinding protein (CREB) (Mayr and Montminy, 2001; Impey et al., 2004), which can be activated by extracellular signals that increase the intracellular levels of cAMP or $\mathrm{Ca}^{2+}$ (Lonze and Ginty, 2002; West et al., 2002; Conkright et al., 2003). cAMPdependent regulation of transcription via CREB has been implicated in neurogenesis, cell survival, synaptic transmission and cognitive function in the normal nervous system and may be defective in developmental, psychiatric and neurodegenerative disorders (Barco et al., 2002; Lonze and Ginty, 2002; Nguyen and Woo, 2003; Carlezon et al., 2005).

CREB activation requires phosphorylation of serine-133, which can be mediated by PKA, the mitogen-activated protein kinase (MAPK) pathway, or $\mathrm{Ca}^{2+} /$ calmodulin-dependent kinases (CaMKs), depending on the activating signal and cell type (Gonzalez and Montminy, 1989; Sheng et al., 1991; Dash et al., 1991). Although CREB phosphorylation is necessary, it may not be sufficient to initiate gene transcription. In many cells, an additional step, e.g., activation of a transcriptional coactivator such as CREB binding protein (CBP/p300; TOX3) (Arias et al., 1994; Brindle et al., 1995; Yuan et al., 2009), is necessary for the assembly of an active RNA polymerase complex and initiation of tran- 
scription (Hardingham et al., 1999; Cardinaux et al., 2000; Vo and Goodman, 2001; Xu et al., 2007). Whether activation of both CREB and coactivator is mediated by cAMP- or $\mathrm{Ca}^{2+}$-dependent kinases may depend on cell-specific kinase expression patterns (Matthews et al., 1994; Impey et al., 2002).

Here, we report that, in immature neurons from embryonic mouse cortex, prior to synaptogenesis, DA and cAMP do not stimulate CREB-dependent gene transcription when NMDA receptors (NMDARs) are blocked. Our results suggest that cAMP stimulates CREB-dependent gene transcription via a two-step process by inducing release of an excitatory amino acid, identified here as L-aspartate, which then activates NMDARs, leading to $\mathrm{Ca}^{2+}$ entry and gene transcription.

\section{Materials and Methods}

Cell cultures. Cultured neurons from embryonic day 15.5 (E15.5) C57BL/6 mouse cortex were maintained in 24-well plates coated with polyornithine and laminin at a density of $3 \times 10^{5}$ cells/well. Culture medium was B27-supplemented Neurobasal (Invitrogen) containing 1 $\mathrm{mm}$ glutamine, penicillin and streptomycin. Cells were grown in $0.5 \mathrm{ml}$ of medium per well and the medium was not changed. All experiments were conducted at $4-5$ days in vitro (DIV). Although the cultured cells at this age are postmitotic neurons, which have elaborated extensive processes and express neuron-specific immunohistochemical markers, synaptogenesis has not yet begun (cf. Hardingham and Bading, 2002; Han and Stevens, 2009). Cortical astrocyte cultures from E15.5 C57BL/6 mouse embryos were maintained in poly-L-lysine-coated T75 flasks in DMEM/ F12 medium (1/1) supplemented with 10\% heat-inactivated fetal bovine serum (Atlanta Biologicals) and penicillin/streptomycin. Before transfection, astrocytes were replated into 24 -well plates $\left(5 \times 10^{5}\right.$ cells/well; $0.5 \mathrm{ml}$ of medium/well).

Transfection, plasmids, and luciferase reporter assays. Cortical neurons were transfected at 3 DIV by the $\mathrm{Ca}^{2+}$-phosphate method (Xia et al., 1996). Astrocytes were transfected 1-2 d after replating using Lipofectamine 2000 (Invitrogen) diluted 1:33 in Opti-MEM without penicillin/streptomycin. The 4xCRE reporter consisted of four CREs inserted in pCIC-CK vector (Stratagene) upstream of the luciferase reporter gene. In control experiments, empty pCIC-CK plasmid was not stimulated by any of the agonists used in this study (data not shown) (see Kingsbury et al., 2003). Cotransfection with constitutively active TK Renilla plasmid (DualLuciferase Reporter Assay System, Promega) served as a control for variability in transfection efficiency and cell density. Experiments were conducted $24 \mathrm{~h}$ after transfection. Luciferase activity was measured with a Centro LB 960 microplate luminometer (Berthold). The ratio of 4xCRE luciferase and Renilla activities was computed for each sample and the mean of triplicate determinations was expressed as a fraction of unstimulated activity. The result for each experimental condition is reported as mean \pm SEM $(n=3-5)$, where $n$ is the number of independent experiments. Statistical analyses were conducted with ANOVA followed by Tukey test using InStat (GraphPad).

cAMP assay. Intracellular cAMP levels were measured by ELISA (Assay Designs); cAMP levels are reported as picomoles $/ 10^{6}$ cells.

Quantitative real-time PCR. Neurons were cultured for 3-4 d in $35 \mathrm{~mm}$ culture dishes at a density of $1.2 \times 10^{6}$ cells/dish and then stimulated for 1,3 or $24 \mathrm{~h}$. Total RNA was purified with RNeasy Mini Kit (Qiagen) including the on-column DNA digestion step. This procedure regularly gave high purity RNA $(260 / 280 \mathrm{~nm}$ absorbance ratio $\sim 2.0)$. cDNA was reversetranscribed (Transcriptor Kit, Roche) using random primers. Reactions were run in a LightCycler 480 (Roche) using SYBR Green I Master Mix (Roche) with the following settings: preincubation $\left(5 \mathrm{~min}\right.$ at $\left.95^{\circ} \mathrm{C}\right)$; amplification, 45 cycles $\left(10 \mathrm{~s}\right.$ at $95^{\circ} \mathrm{C} ; 15 \mathrm{~s}$ at $58^{\circ} \mathrm{C} ; 1 \mathrm{~min}$ at $\left.72^{\circ} \mathrm{C}\right)$; and a melting curve $\left(5 \mathrm{~s}\right.$ at $95^{\circ} \mathrm{C}$ followed by $1 \mathrm{~min}$ ramp from $65^{\circ} \mathrm{C}$ to $97^{\circ} \mathrm{C}$ ). All samples generated single melting curve peaks. Primers were used at $0.5 \mu \mathrm{M}$ concentration and had the following sequences. GAPDH: 5-TGATGACATCAAGAAGGTGGTGAAG-3 (forward) and 5-TCCTTGGAGGCCATGTAGGCCAT-3 (reverse), c-fos: 5-AAGTTGGCACTAGAGACGGACAGA-3 (forward) and 5-ACTTCGACCATGATGTTCTCGGGT-3 (reverse),
BDNF-exon I: 5-GGACAGCAAAGCCACAATGTTCCA-3 (forward) and 5-TTGCCTTGTCCGTGGACGTTTACT-3 (reverse) and BDNF-exon IV: 5-ACCAGGTGAGAAGAGTGATGACCA-3 (forward) and 5-GTTGCCTTGTCCGTGGACGTTTA-3 (reverse).

Each sample was run in duplicate and a three-point (400, 200, and 100 ng) cDNA dilution curve was constructed. The reaction efficiency was calculated for each treatment condition. RNA for each target gene was normalized to GAPDH according to the following formula (Pfaffl, 2001):

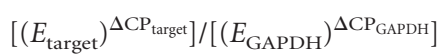

where $E_{\text {target }}$ and $E_{\mathrm{GAPDH}}$ are the reaction efficiencies for the target and GAPDH PCR, respectively, and $\triangle \mathrm{CP}$ is the difference between the crossing thresholds of the control and experimental samples. This equation takes into account the actual measured reaction efficiency for each treatment condition, rather than assuming a theoretical efficiency of 2.0.

Western blot. Neurons grown in polyornithine/laminin-coated $35 \mathrm{~mm}$ plastic dishes were stimulated for $3 \mathrm{~h}$, washed in ice-cold PBS and lysed with Ripa Buffer (Sigma-Aldrich) supplemented with protease (Roche Applied Science) and phosphatase (Pierce) inhibitors. Samples were run in duplicate on precast $4-12 \%$ Bis-Tris gels (Invitrogen) and transferred to PVDF membranes. Blots were blocked for $1 \mathrm{~h}$ with Tris-buffered saline containing $0.01 \%$ Tween-20, $5 \%$ powered milk and $5 \%$ bovine albumin (Sigma-Aldrich). Membranes were incubated overnight at $4^{\circ} \mathrm{C}$ with antibody to phospho-S133-CREB (Cell Signaling Technology) diluted 1:1000 and incubated with secondary horseradish peroxidase-linked antibodies (GE Healthcare) at room temperature for $1 \mathrm{~h}$. Bands were visualized by enhanced chemiluminescence (Millipore) and images were acquired and analyzed on an Image Station 2000R (Kodak-Carestream Health). Uniform loading was verified by stripping and reprobing with antibodies to total CREB (1:1000; Cell Signaling Technology).

Glutamate and aspartate scavenging systems. To degrade glutamate in the extracellular space, cultures were incubated with $5 \mathrm{U} / \mathrm{ml}$ glutamatepyruvate transaminase (GPT) and $10 \mathrm{~mm}$ pyruvate for $20 \mathrm{~min}$ before stimulation with forskolin. To degrade both L-aspartate and glutamate, cultures were incubated with $5 \mathrm{U} / \mathrm{ml} \mathrm{GPT}, 10 \mathrm{~mm}$ pyruvate, $5 \mathrm{U} / \mathrm{ml}$ glutamate-oxaloacetate transaminase (GOT) and $3 \mathrm{~mm} \alpha$-ketoglutarate ( $\alpha$-keto) for $20 \mathrm{~min}$ before stimulation with forskolin. Omission of GPT and GOT served as controls.

Excitatory amino acid analysis. At 4 DIV, medium $(500 \mu \mathrm{l})$ from neurons in 24 well plates was removed and replaced by $200 \mu \mathrm{l}$ of fresh medium; cells were stimulated by addition of forskolin $4 \mathrm{~h}$ later. HPLC was used to quantify aspartate and glutamate in $250 \mu \mathrm{l}$ of the combined culture medium from two duplicate wells. Samples were acidified with $0.14 \mathrm{M}$ perchloric acid and neutralized with $0.25 \mathrm{M}$ potassium bicarbonate. Samples were reacted with 2 volumes of $o$-phthalaldehyde (OPA) for 2 min before injection on to a C18 reverse phase column (BeckmanCoulter). Derivatized amino acids were detected by fluorescence. The elution was performed at $0.7 \mathrm{ml} / \mathrm{min}$ with a linear gradient mixing $7.5 \%$ methanol prepared in $20 \mathrm{~mm}$ sodium acetate, $\mathrm{pH} 7$ (solution A) with $30 \%$ methanol and $30 \%$ acetonitrile prepared in water (solution B). Over the range encompassing aspartate, the gradient ran for 15 min from $97 \%$ A and $3 \% \mathrm{~B}$ to $85 \% \mathrm{~A}$ and $15 \% \mathrm{~B}$. The column was stripped with $100 \% \mathrm{~B}$ following the elution of aspartate and glutamate. The positions of aspartate and glutamate on the chromatogram were identified by running standards and confirmed by spiking experimental samples with these amino acids.

Drugs and reagents. Forskolin, 8-Br-cAMP, NMDA, DL-AP5 (DL-2-amino-5phosphonopentanoic acid), ifenprodil, SKF38393 ( $\pm 2,3,4,5$-tetrahydro-7, 8-dihydroxy-1-phenyl-1 H-3-benzazepine), SCH23390 [R-(+)-7-chloro-8hydroxy-3-methyl-1-phenyl-2,3,4,5-tetrahydro- $1 \mathrm{H}$-3-benzazepine], pyruvate, glutamate-pyruvate transaminase (from porcine heart), glutamate-oxaloacetate transaminase type I (from porcine heart), L-glutamate, L-aspartate, OPA, and $\alpha$-ketoglutarate were obtained from Sigma-Aldrich; H89 (N-[2-((pbromocinnamyl)amino)ethyl]-5-isoquinolinesulfonamide), dideoxyforskolin, and Bapta-AM from EMD-Calbiochem; Bapta-free acid from Invitrogen; TBOA (DL-threo- $\beta$-benzyloxyaspartic acid) and trans-PDC (L-trans-pyrrolidine-2,4-dicarboxylic acid) from Tocris Bioscience, and EGTA-AM from AnaSpec. Antagonists were added 30 min before stim- 
ulation except for Bapta-AM and EGTA-AM which were added $60 \mathrm{~min}$ before stimulation.

\section{Results}

Stimulation of CREB-dependent transcription by cAMP requires $\mathrm{Ca}^{2+}$ Neuron cultures from E15.5 mouse cortex were transfected at $3 \mathrm{~d}$ in vitro ( $3 \mathrm{DIV})$ with a luciferase reporter construct driven by 4 tandem CREs ( $4 \mathrm{x} C R E)$. The next day, the cells were incubated with the ACactivator, forskolin, and harvested after $5 \mathrm{~h}$ for measurement of luciferase activity. A maximally effective concentration of forskolin (10 $\mu \mathrm{M}$ ) induced a 16-fold stimulation of $4 \mathrm{xCRE}$ luciferase reporter activity (Fig. $1 a)$, whereas the inactive derivative, dideoxy-forskolin, had no effect, even at $30 \mu \mathrm{M}$ (supplemental Fig. S1, available at www.jneurosci.org as supplemental material). Stimulation by cAMP was found to require $\mathrm{Ca}^{2+}$. Preincubation of the cultures with either $10 \quad \mu \mathrm{M} \quad$ 1,2-bis(o-aminophenoxy) ethane- $N, N, N^{\prime}, N^{\prime}$-tetraacetic acid-acetoxymethyl ester (Bapta-AM) to chelate intracellular $\mathrm{Ca}^{2+}$, or $3 \mathrm{~mm}$ Bapta-free acid (FA) to chelate extracellular $\mathrm{Ca}^{2+}$, completely inhibited $4 \mathrm{x} C R E$ stimulation by forskolin (Fig. 1a). Stimulation by forskolin was also inhibited by the cAMP-dependent protein kinase (PKA) antagonist, H89 (10 $\mu \mathrm{M}$ ) (supplemental Fig. S1, available at www.jneurosci.org as supplemental material). The membrane-permeant cAMP analog, 8-Br-cAMP, also stimulated 4xCRE luciferase expression and, as with forskolin, stimulation was blocked by chelation of intracellular (Bapta-AM) or extracellular (Bapta-FA) $\mathrm{Ca}^{2+}$ (Fig. 1a). Since 8-Br-cAMP acts independently of adenylyl cyclase, $\mathrm{Ca}^{2+}$ is required for a signaling step downstream from cAMP.

\section{$\mathrm{Ca}^{2+}$ is not required for stimulation of cAMP production by forskolin}

The $\mathrm{Ca}^{2+}$ dependence of both 8-Br-cAMP- and forskolininduced CREB-dependent gene transcription suggests that forskolin is not activating a $\mathrm{Ca}^{2+}$-dependent AC. To determine whether $\mathrm{Ca}^{2+}$ is required for forskolin to stimulate cAMP production, we examined the effect of a $\mathrm{Ca}^{2+}$ chelator on forskolininduced cAMP production in neuron cultures. A maximally effective concentration of forskolin $(10 \mu \mathrm{M})$ increased the level of cAMP by 12 -fold as measured by ELISA (Fig. 1b). Despite the $\mathrm{Ca}^{2+}$ requirement for cAMP to stimulate $4 \mathrm{xCRE}$ expression (Fig. $1 a)$, the forskolin-induced rise in cAMP was unaffected by preincubation with $10 \mu \mathrm{M}$ Bapta-AM, indicating that forskolin is not activating a $\mathrm{Ca}^{2+}$-dependent $\mathrm{AC}$.

\section{Stimulation of CREB-dependent transcription by forskolin requires an increase in $\mathrm{Ca}^{2+}$ within a microdomain}

We did not observe an increase in intracellular neuronal $\mathrm{Ca}^{2+}$ in response to forskolin as measured by $\mathrm{Ca}^{2+}$ imaging (data not shown), raising the possibility that spatially restricted rather than global $\mathrm{Ca}^{2+}$ increases mediate the effects of forskolin on CREBdependent gene transcription. To investigate this possibility, we compared the effects of Bapta-AM and EGTA-AM on cAMPinduced CREB-dependent transcription. The on-rate for $\mathrm{Ca}^{2+}$ binding to Bapta is fast compared with the rate of intracellular $\mathrm{Ca}^{2+}$ diffusion and intracellular Bapta quickly buffers increases b

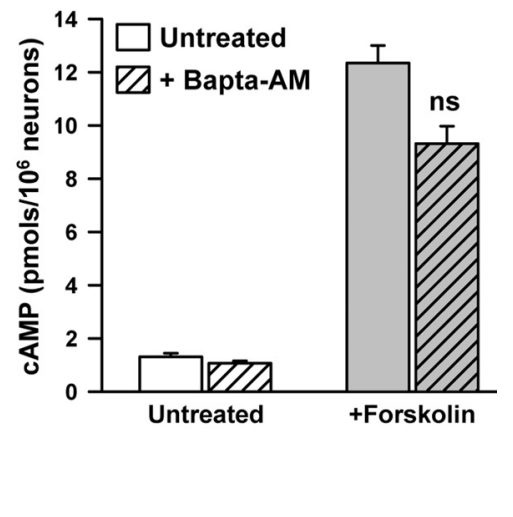

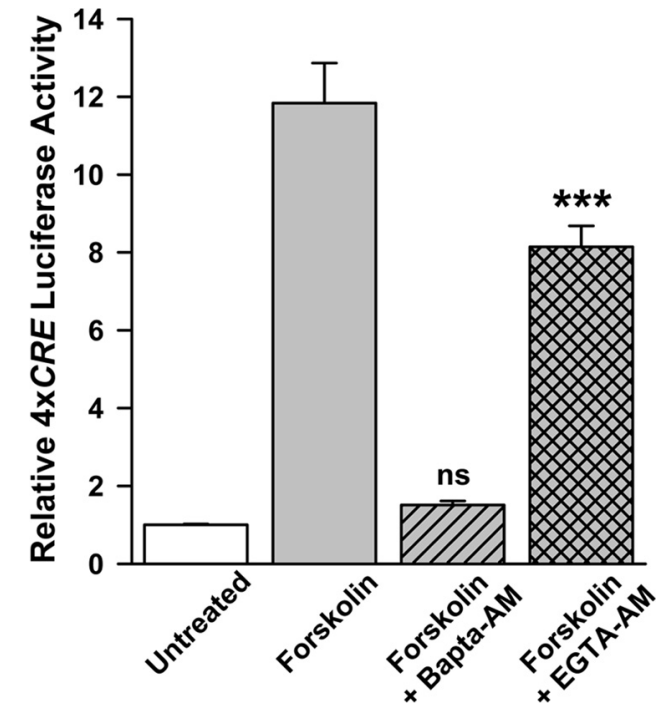

Figure 2. Stimulation of CREB-dependent transcription by forskolin requires an increase in $\left[\mathrm{Ca}^{2+}\right]$ within a microdomain. One day after transfecting with $4 \times C R E$ reporter plasmid, cultures were preincubated with Bapta-AM or EGTA-AM $(10 \mu \mathrm{m})$ for $1 \mathrm{~h}$ and then stimulated by addition of $10 \mu \mathrm{m}$ forskolin. Cells were harvested $5 \mathrm{~h}$ later for luciferase assays. Bapta completely inhibited forskolin-induced 4xCRE expression, whereas EGTA only inhibited by $\sim 30 \%$. ***Significantly different from forskolin + Bapta-AM ( $p<0.001)$; ns, not significantly different from untreated.

in intracellular $\mathrm{Ca}^{2+}$. In contrast, the on-rate for $\mathrm{Ca}^{2+}$ binding to EGTA is slow. Consequently, unlike Bapta, EGTA will not buffer $\mathrm{Ca}^{2+}$ fast enough to prevent activation of $\mathrm{Ca}^{2+}$-dependent processes within the microdomain in the vicinity of $\mathrm{Ca}^{2+}$ entry (Deisseroth et al., 1996; Naraghi and Neher, 1997; Hardingham et al., 2001; Augustine et al., 2003). When EGTA-AM was substituted for Bapta-AM, stimulation of transcription by forskolin was only reduced by $\sim 30 \%$ in contrast to $95 \%$ inhibition by Bapta (Fig. 2), suggesting that increased $\mathrm{Ca}^{2+}$ within such microdomains mediates the stimulation of CREB-dependent gene transcription by cAMP. 

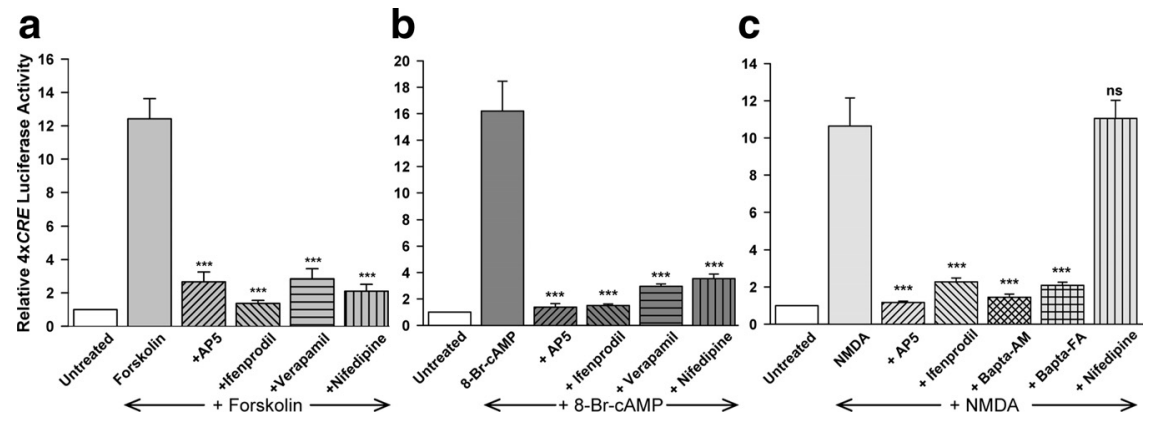

Figure 3. Stimulation of CREB-dependent gene transcription requires activation of NR2B-containing NMDARs and L-type $\mathrm{Ca}_{\mathrm{v}} \mathrm{s}$. $\boldsymbol{a}, \boldsymbol{b}$, Induction of $4 \times C R E$ transcription by $10 \mu \mathrm{m}$ forskolin $(\boldsymbol{a})$ or $3 \mathrm{~mm} 8$ 8-Br-CAMP $(\boldsymbol{b})$ was blocked by the NMDAR antagonists AP5 $(100 \mu \mathrm{M})$ or ifenprodil $(10 \mu \mathrm{M})$ and by the L-type $\left(\mathrm{a}_{v}\right.$ antagonists verapamil $(100 \mu \mathrm{M})$ or nifedipine $(100 \mu \mathrm{M})$. c, Activation of NMDARs with NMDA (30 $\mu \mathrm{m}+10 \mu \mathrm{m}$ glycine) induced 4xCRE transcription that was sensitive to AP5 (100 $\mu \mathrm{M}$ ) or ifenprodil (10 $\mu \mathrm{M}$ ), but not to $\mathrm{Ca}_{\mathrm{v}}$ antagonists. Similarly, NMDA-stimulated 4xCRE expression was blocked by Bapta-free acid (Bapta-FA; $3 \mathrm{~mm}$ ) or by pretreating neurons with $10 \mu \mathrm{m}$ Bapta-AM. The L-type $\mathrm{C}_{\mathrm{v}}$ antagonist, nifedipine $(100 \mu \mathrm{M})$, did not reduce NMDA-stimulated 4xCRE transcription. ${ }^{* * *}$ Significantly different from agonist only $(p<0.001)$; ns, not significantly different from NMDA only.

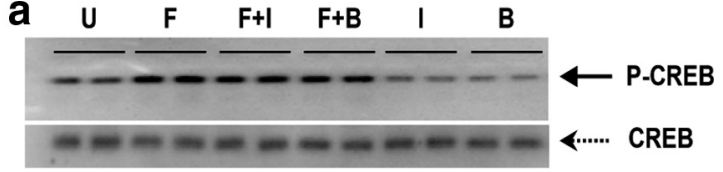

b

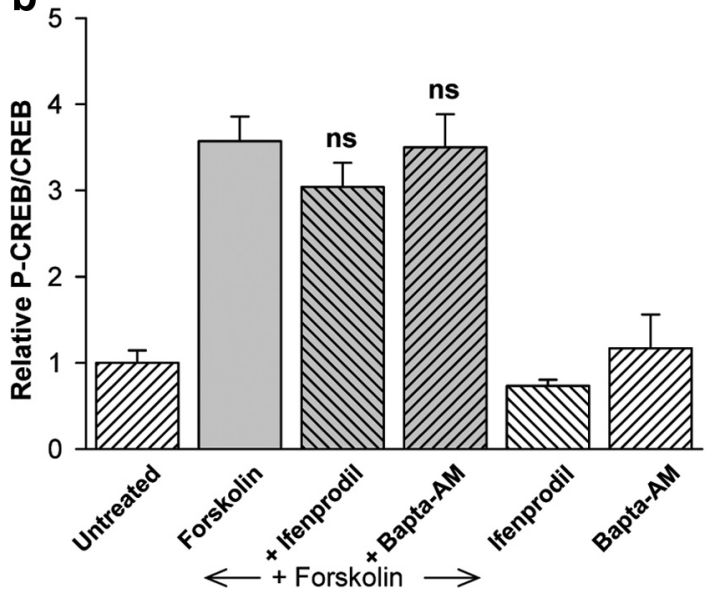

Figure 4. Phosphorylation of CREB at serine-133 is not sufficient for $4 \times C R E$ transcription. a, Immunoblots were probed for phospho-CREB (top) and then stripped and reprobed for total CREB (bottom) to control for sample variability. Forskolin (F; $10 \mu \mathrm{m}$ ) stimulated CREB phosphorylation when compared with untreated $(U)$ cells. CREB phosphorylation induced by forskolin was insensitive to addition of ifenprodil ( $\mathrm{F}+\mathrm{I})$ or Bapta-AM $(\mathrm{F}+\mathrm{B})$. The effects of forskolin were abolished by incubation with the PKA inhibitor, $\mathrm{H} 89$ (10 $\mu \mathrm{M}$ ) (data not shown). $\boldsymbol{b}$, Quantification of CREB phosphorylation (P-CREB/CREB) from 4 experiments; $n s$, not significantly different from forskolin alone.

Stimulation of transcription by cAMP requires activation of both NR2B-containing NMDARs and L-type, voltage-gated $\mathrm{Ca}^{2+}$ channels

Since the results in Figure $1 a$ suggested that $4 \mathrm{x} C R E$ activation by cAMP requires $\mathrm{Ca}^{2+}$ influx, we examined the effects of inhibitors of the two principal $\mathrm{Ca}^{2+}$ entry pathways in neurons, the NMDA class of ionotropic glutamate receptors (NMDARs) and voltage-gated $\mathrm{Ca}^{2+}$ channels $\left(\mathrm{Ca}_{\mathrm{v}} \mathrm{s}\right)$. AP5, an antagonist of all subtypes of NMDARs; ifenprodil, a selective inhibitor of NMDARs containing NR2B subunits; as well as nifedipine and verapamil, inhibitors of L-type $\mathrm{Ca}_{\mathrm{v}} \mathrm{s}$, each blocked cAMPstimulated 4xCRE-luciferase expression by at least $90 \%$ (Fig. 3a,b). NMDA, which directly activates NMDARs, also stimulated $4 \mathrm{x} C R E$ luciferase activity; this stimulation was blocked by AP5 and ifenprodil, but not by nifedipine (Fig. $3 c$ ). Thus, while $\mathrm{Ca}^{2+}$ entering through both NMDARs and $\mathrm{Ca}_{\mathrm{v}} \mathrm{s}$ is necessary for cAMP to stimulate $4 \mathrm{xCRE}$ transcription (Fig. 3a,b), 4xCRE transcription induced by strong stimulation of NMDARs (Fig. 3c) does not require $\mathrm{Ca}_{\mathrm{v}} \mathrm{s}$.

cAMP-induced CREB phosphorylation is not sufficient for transcription Activation of CRE-dependent gene expression by either CAMP or $\mathrm{Ca}^{2+}$ requires phosphorylation of CREB at serine-133 (Dash et al., 1991; Lonze and Ginty, 2002). Western blot analysis with antibodies specific for phosphorylated CREB serine-133 revealed that forskolin stimulation of CREB phosphorylation was not affected by Bapta-AM or ifenprodil (Fig. 4), both of which blocked forskolinstimulated 4xCRE transcription (Figs. 1a,3a). Forskolin-induced CREB phosphorylation was inhibited by the PKA antagonist, H89 (data not shown). Thus, unlike CREB-dependent gene transcription, stimulation of CREB phosphorylation by CAMP is $\mathrm{Ca}^{2+}$ independent and does not require NMDARs. These data suggest that an additional, $\mathrm{Ca}^{2+}$-dependent step, mediated by NMDAR activation, is required for cAMP to stimulate $4 \mathrm{x} C R E$ transcription.

\section{DA-induced CREB-dependent gene transcription is mediated by NMDARs}

DA is a major endogenous neurotransmitter in the cortex as well as in the hippocampus and striatum (Goldman-Rakic et al., 2000). DA acting at the D1/D5 class of DA receptors, which are positively coupled to adenylyl cyclase, stimulates cAMP production. Application of $100 \mu \mathrm{M}$ DA to cortical neurons stimulated CREB-dependent gene transcription and this effect was potentiated by the cyclic nucleotide phosphodiesterase inhibitor, rolipram (Fig. 5a). Isoproterenol, an agonist of $\beta$-adrenergic receptors, which are also positively linked to AC in some neurons, did not stimulate CREB-dependent gene transcription in either the absence or presence of rolipram (Fig. $5 a$ ). Stimulation by $\mathrm{DA}+$ rolipram was fully blocked by Bapta-AM (10 $\mu \mathrm{M})$, AP5 (100 $\mu \mathrm{M})$, ifenprodil $(10 \mu \mathrm{M})$, verapamil $(100 \mu \mathrm{M})$, as well as by the D1 DA receptor antagonist, SCH23390 (30 $\mu \mathrm{M})$ (Fig. 5b). Thus, like forskolin and 8-Br-cAMP (Fig. 3a,b), the endogenous transmitter, DA, which acts via cAMP, does not activate CREB-dependent gene transcription when NR2B-containing NMDARs or L-type $\mathrm{Ca}_{\mathrm{v}} \mathrm{s}$ are blocked.

Stimulation of endogenous $B D N F$ and $c$-fos transcription by cAMP and DA agonists is also mediated by NR2B-containing NMDARs

To determine whether cAMP activation of endogenous CREBdependent gene transcription also requires NMDARs, we examined the effect of forskolin and the D1/D5 DA receptor agonist, SKF38393 (Johnson et al., 1992), on levels of mRNAs encoding the endogenous $C R E$-containing genes, $\mathrm{c}$-fos and $B D N F$ (exons I and IV). $\mathrm{Ca}^{2+}$ - and cAMP-dependent $B D N F$ transcription is mediated by CREs in exons I and IV (Tabuchi et al., 2002; West et al., 2002). We found that, while forskolin strongly stimulated $c$-fos mRNA expression within $1 \mathrm{~h}$ and BDNF exon I expression was maximal by $3 \mathrm{~h}$, exon IV expression was not substantially increased until $24 \mathrm{~h}$ (supplemental Fig. S2, available at www. 
jneurosci.org as supplemental material). At $24 \mathrm{~h}$, stimulation of mRNA encoding $c$-fos and both $B D N F$ isoforms by forskolin and SKF38393 was inhibited by ifenprodil (Fig. 6). Thus, our finding that stimulation of CRE-dependent gene transcription by DA via cAMP requires activation of NR2B-containing NMDARs is not limited to the $4 \mathrm{x} C R E$ reporter and may reflect a common regulatory mechanism of CREB-dependent genes in these neurons.

\section{An excitatory amino acid mediates stimulation of CREB-dependent transcription by cAMP}

The block of cAMP-induced, CREBdependent gene transcription by AP5 and ifenprodil led us to hypothesize that cAMP induces an increase in the extracellular level of an activator of the NMDAR, viz., an excitatory amino acid (EAA) secreted by the neurons themselves. Stimulation of neurotransmitter release by cAMP is consistent with several reports in the literature (Chavez-Noriega and Stevens, 1994; Trudeau et al., 1996; Lu et al., 2004; Seino and Shibasaki, 2005; Woodhall et al., 2007). To test this hypothesis, we preincubated the neurons with the EAA uptake inhibitor, TBOA, which would be predicted to potentiate the effects of CAMP. TBOA $(10 \mu \mathrm{M})$ alone had a negligible effect on $4 \mathrm{x} C R E$ transcription but potentiated the effects of forskolin and 8-Br-cAMP (Fig. 7). Similar potentiation of the effects of forskolin was obtained with a structurally different EAA uptake inhibitor, trans-PDC (supplemental Fig. S3, available at www.jneurosci.org as supplemental material). These results suggested that extracellular glutamate or aspartate mediates the stimulation of CREB-dependent gene transcription by cAMP.

\section{Aspartate mediates stimulation of CREB-dependent transcription by cAMP}

If glutamate were the mediator of cAMP-induced CREBdependent gene transcription, the response should be blocked by an enzymatic glutamate scavenging system (glutamate-pyruvate transaminase, GPT; cf., O'Brien and Fischbach, 1986; Matthews et al., 2003). In control experiments, the combination of pyruvate plus GPT reduced added glutamate to undetectable levels and completely inhibited stimulation of $4 \mathrm{x} C R E$ by added glutamate, demonstrating the efficacy of this scavenging system (supplemental Fig. S4, available at www.jneurosci.org as supplemental material). However, this glutamate scavenger system had no effect on stimulation by forskolin (Fig. 8a). This raised the possibility that aspartate (Fleck et al., 1993; Bradford and Nadler, 2004) rather than glutamate mediates the effects of cAMP in these neurons. To investigate the possible role of aspartate in mediating the stimulation of CRE-dependent transcription by cAMP, we developed a novel aspartate + glutamate scavenging system by adding $\alpha$-keto and GOT to the glutamate scavenging system. GOT converts $\alpha$-keto and L- (but not D-) aspartate to glutamate and oxaloacetate. Thus, both L-aspartate and glutamate are degraded in the presence of GOT, $\alpha$-keto, GPT and pyruvate. This combination scavenging system completely inhibited stimulation of CREB-dependent gene transcription by forskolin (Fig. $8 b$ ), in contrast to the glutamate-only scavenging system, which

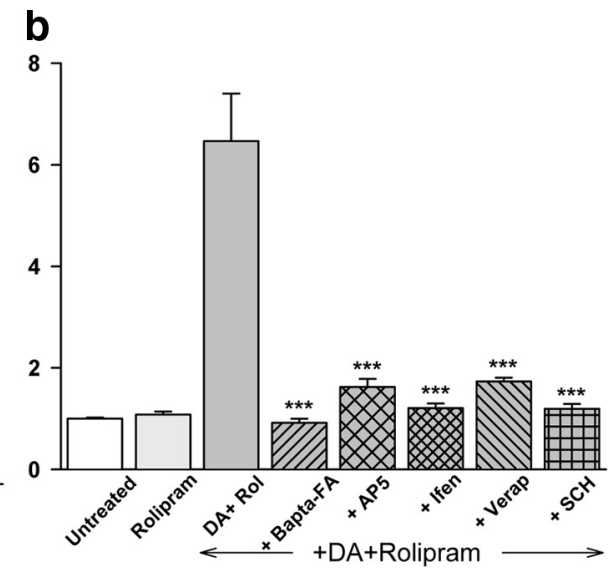

Figure 5. DA activates CREB-dependent gene transcription. $\boldsymbol{a}$, Cortical neurons transfected with $4 \times C R E$ luciferase were stimulated at 4 DIV with DA $(100 \mu \mathrm{M})$ or the $\beta$-adrenergic agonist, isoproterenol $(100 \mu \mathrm{m})$, in the absence or presence of $0.1 \mu \mathrm{m}$ rolipram for $5 \mathrm{~h}$ and then harvested for luciferase assay. ${ }^{* *}$ Significantly different from untreated neurons, $p<0.005$; ${ }^{* * *}$ significantly DA alone, $p<0.001 ; n$ s, not significantly different from untreated control; $n=3$ experiments. $\boldsymbol{b}$, Stimulation by (100 $\mu \mathrm{M})$; this pharmacological profile is identical to that observed with stimulation by CAMP (Fig. 3a,b). The D1 DA receptor $\mathrm{DA}+$ rolipram, $p<0.001$. Ascorbic acid $(100 \mu \mathrm{M})$ was included to reduce DA oxidation; control experiments demonstrated that ascorbic acid did not stimulate $4 \times C R E$ expression (data not shown).

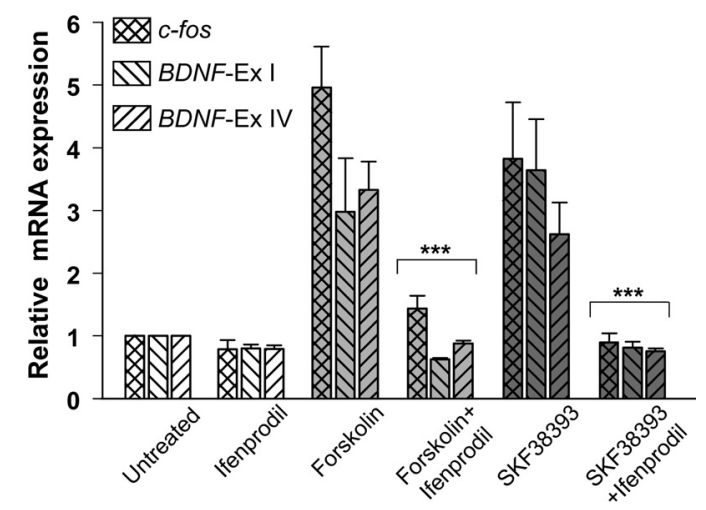

Figure 6. Stimulation of mRNA levels of CRE-containing genes by CAMP or D1 DA receptor agonist is mediated by NR2B-containing NMDARs. Cortical neuron cultures were incubated for $24 \mathrm{~h}$ in the absence or presence of forskolin $(10 \mu \mathrm{M})$, the D1 agonist, SKF38393 $(100 \mu \mathrm{M})$ and/or ifenprodil $(10 \mu \mathrm{m})$ and cells were harvested for RNA extraction. After reverse transcription, levels of $c$-fos, and exons I and IV of BDNF were determined by quantitative real-time PCR. Data are expressed relative to untreated cultures. ${ }^{* *}$ Significantly different from corresponding cultures stimulated by forskolin or SKF38393; $p<0.001$.

had no effect (Fig. 8a). Thus, extracellular L-aspartate, but not glutamate, mediates the effect of cAMP on CREB-dependent gene transcription. Because aspartate specifically activates NMDARs, whereas glutamate activates mGluRs and AMPARs as well as NMDARs (Curras and Dingledine, 1992; Frauli et al., 2006), increased cAMP will initiate selective activation of NMDARs on the target cells.

cAMP induces release of aspartate in cortical neuron cultures The inhibition of cAMP-induced CREB-dependent gene transcription by the aspartate + glutamate scavenger system suggested that cAMP induces release of aspartate. Using high-resolution HPLC, we directly demonstrated that treatment with forskolin for 30 min induced a significant increase in aspartate levels in the medium (Fig. 9). In contrast, glutamate levels in the medium were unchanged in the same cultures. This finding also suggests 


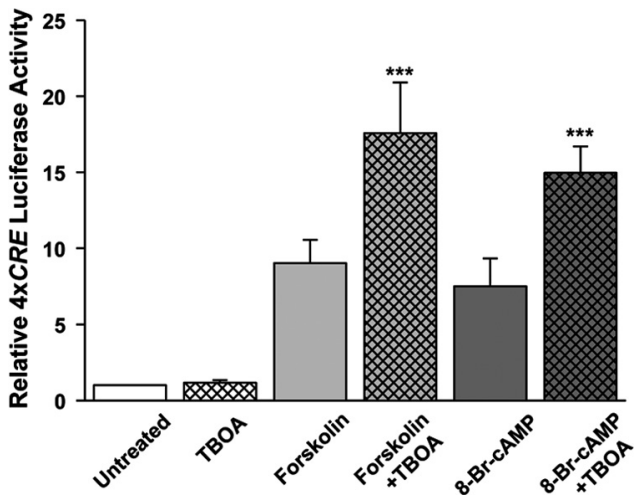

Figure 7. EAA uptake inhibition enhances stimulation of CREB-dependent gene transcription by CAMP. The EAA uptake inhibitor, TBOA $(10 \mu \mathrm{m})$ did not, by itself, stimulate $4 \times C R E$ transcription, but potentiated the response induced by forskolin (1 $\mu \mathrm{M})$ or 8-Br-CAMP (1 mM). ***Significantly different from forskolin or 8-Br-cAMP alone $(p<0.001)$.

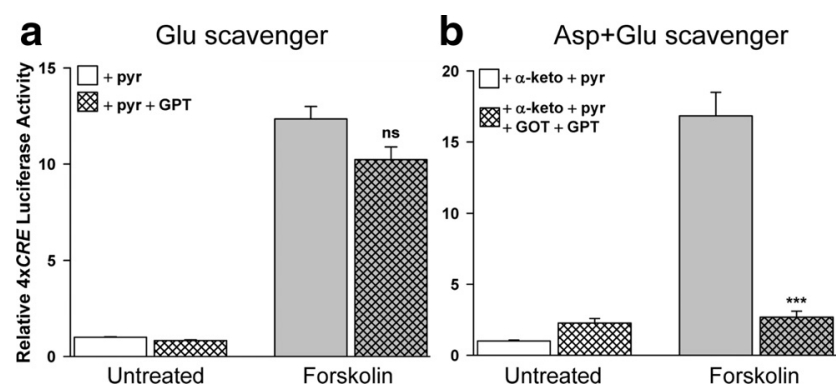

Figure 8. L-Aspartate + glutamate scavenger inhibits CAMP-induced $4 x C R E$ transcription but glutamate scavenger does not. $\boldsymbol{a}$, Addition of a glutamate-only scavenging system (10 mm pyruvate plus $5 \mathrm{U} / \mathrm{ml}$ GPT) did not affect forskolin-induced $4 \times C R E$ transcription. $\boldsymbol{b}$, Addition of an L-aspartate + glutamate scavenging system (10 mm pyruvate plus $5 \mathrm{U} / \mathrm{ml} \mathrm{GPT;} 3 \mathrm{~mm} \alpha$-ketoglutarate plus $5 \mathrm{U} / \mathrm{ml}$ GOT) completely inhibited the response to forskolin. ns, Not significantly different from forskolin alone; ${ }^{* * *}$ significantly different from forskolin alone ( $p<0.001$ ).

that aspartate and glutamate release are independently regulated and that aspartate is not simply coreleased with glutamate. It should be noted that the $50 \%$ increase in aspartate measured after dilution into the bulk medium is likely to be an underestimate of the local increase in aspartate levels in the vicinity of the NMDARs following stimulation by forskolin.

\section{Discussion}

Transcriptional response to cAMP is mediated by aspartate and activation of NMDARs

As summarized in Figure 10, we postulate that stimulation of CREBdependent transcription by cAMP occurs in two sequential steps, viz., cAMP induces release of aspartate (Fig. 10, left, dashed arrows), followed by activation of NR2B-containing NMDARs by the aspartate released in response to cAMP. We refer to this as the cAMP/aspartate/NMDAR signaling pathway. Since all of the experiments reported here were conducted in neuron cultures at 4-5 DIV, before the onset of synaptogenesis, aspartate release (Fig. 9) and activation of NMDARs (Figs. 3, 5b) are not synaptic events. Consequently, we refer to this as an autocrine mechanism (or a paracrine mechanism if the aspartate acts on neighboring neurons).

Our hypothesis is based on several lines of evidence. First, the effects of cAMP and DA on both $4 \mathrm{xCRE}$ (Figs. $3 a, b, 5)$ and $c$-fos and BDNF mRNA expression (Fig. 6) are blocked by NMDAR antagonists. Second, two structurally distinct inhibitors of neu- ronal EAA uptake, TBOA (Fig. 7) and trans-PDC (supplemental Fig. S3, available at www.jneurosci.org as supplemental material), potentiated the stimulation of gene transcription by cAMP. Third, the aspartate+glutamate-, but not the glutamate-only-, scavenging system abolished stimulation of CREB-dependent gene transcription by forskolin (Fig. 8); the aspartate-scavenging enzyme, GOT, degrades L- but not D-aspartate demonstrating that L-aspartate is the active extracellular EAA in this signaling pathway. Finally, forskolin was found to induce release of aspartate but not glutamate (Fig. 9). Together, these results lead to the conclusion that cAMP-induced release of aspartate and the resulting activation of NR2B-containing NMDARs mediate the effects of cAMP. Other studies have reported that cAMP-induced phosphorylation of NMDARs mediated by PKA enhances permeability of the NMDARs to $\mathrm{Ca}^{2+}$ (Dudman et al., 2003; Skeberdis et al., 2006). Our results are not incompatible with this mechanism, which may act in parallel with the autocrine pathway described here to potentiate the effects of cAMP and DA on CREB-dependent transcription.

Figure 10 depicts cAMP-induced aspartate release from neurons acting by an autocrine (or paracrine) mechanism; other mechanisms were also considered. For example, cAMP-induced release of aspartate from a few contaminating astrocytes in the neuron cultures might have contributed to our results. Astrocytes have been reported to release glutamate which activates nearby neurons (Parpura and Haydon, 2000), but only D-aspartate has been reported to be released from astrocytes (Rutledge and Kimelberg, 1996). Moreover, astrocytes, themselves, are not wholly responsible for our results because cAMP-stimulated CREB-dependent gene transcription in purified astrocyte cultures is insensitive to NMDAR antagonists (supplemental Fig. S5, available at www.jneurosci.org as supplemental material). Alternatively, cAMP might specifically inhibit aspartate uptake; however, such an effect of cAMP has not previously been reported. Moreover, aspartate and glutamate are accumulated by the same membrane transporters and forskolin increases aspartate but not glutamate in the medium (Fig. 9). This result argues against inhibition of uptake by cAMP.

We propose that the aspartate-stimulated influx of $\mathrm{Ca}^{2+}$ through NMDARs (Fig. 10, right, solid arrows) is necessary for cAMP to activate gene transcription, even though cAMP can induce CREB phosphorylation in both the presence and absence of NMDAR antagonists (Figs. 4, 10, dotted arrow). Since stimulation of CREBdependent gene transcription requires activation of both CREB and a coactivator, $\mathrm{Ca}^{2+}$ entering through NMDARs appears to be required for coactivator activation (Impey et al., 2002).

\section{$\mathrm{Ca}^{2+}$ microdomains in the cAMP/aspartate/NMDAR signaling pathway}

Our results indicate that $\mathrm{Ca}^{2+}$ entering through NMDARs is a necessary effector for cAMP-stimulated transcription (Figs. $3 a, b$, 10, right, solid arrows). However, we did not observe a global increase in neuronal cytoplasmic $\mathrm{Ca}^{2+}$ in response to forskolin as measured by $\mathrm{Ca}^{2+}$ imaging (data not shown). Unlike Bapta-AM, EGTA-AM had only a small inhibitory effect on cAMP-induced CREB-dependent gene transcription (Fig. 2), suggesting that the relevant increases in $\left[\mathrm{Ca}^{2+}\right]$ occur within distinct microdomains near the site of $\mathrm{Ca}^{2+}$ entry (Deisseroth et al., 1996; Naraghi and Neher, 1997; Hardingham et al., 2001; Augustine et al., 2003) rather than throughout the cytoplasm. 
Role of $\mathrm{Ca}^{2+}$ channels in the cAMP/ aspartate/NMDAR signaling pathway L-type $\mathrm{Ca}_{\mathrm{v}}$ antagonists blocked stimulation of CREB-dependent gene transcription by cAMP (Fig. 3) and D1 DA receptor activation (Fig. 5b), consistent with reports that $\mathrm{Ca}_{\mathrm{v}} \mathrm{s}$ are necessary for glutamate-induced c-fos expression in striatal neurons ( $\mathrm{Ra}-$ jadhyaksha et al., 1999) and forskolininduced proenkephalin gene expression in rat striatal neurons (Konradi et al., 2003). However, block of $\mathrm{Ca}_{\mathrm{v}} \mathrm{s}$ did not affect forskolin-induced aspartate release (supplemental Fig. S6a, available at www. jneurosci.org as supplemental material), suggesting that the $\mathrm{Ca}^{2+}$ entry through $\mathrm{Ca}_{\mathrm{v}} \mathrm{s}$ required for CREB-dependent gene transcription is not necessary for forskolininduced aspartate release. In addition, block of $\mathrm{Ca}_{\mathrm{v}} \mathrm{s}$ did not affect stimulation of $4 \mathrm{x} C R E$ expression by submaximal concentrations of aspartate (supplemental Fig. S6b, available at www.jneurosci.org as supplemental material), suggesting that opening of $\mathrm{Ca}_{\mathrm{v}} \mathrm{s}$ induced by NMDAR activation is not likely to mediate the response to cAMP. These results might be reconciled if a low, constitutive rate of $\mathrm{Ca}^{2+}$ entry through $\mathrm{Ca}_{\mathrm{v}} \mathrm{s}$ were to play a permissive role by maintaining the resting $\mathrm{Ca}^{2+}$ concentration within the relevant microdomain close to the threshold for cAMP-induced transcription. Although channels with such properties have not been reported in neurons, a neuronal L-type $\mathrm{Ca}^{2+}$ channel isoform $\left(\mathrm{Ca}_{\mathrm{v}} 1.2\right)$ that is constitutively active at the resting potential has been described in arterial myocytes (Navedo et al., 2005).

\section{Glutamate receptor specificity of} cAMP-induced aspartate release

The involvement of aspartate as an extracellular messenger in the cAMP/aspartate/ NMDAR pathway has potentially interesting implications regarding the specificity of the response because, unlike glutamate, aspartate does not activate either AMPA receptors (Curras and Dingledine, 1992) or mGluRs (Frauli et al., 2006). If glutamate were the messenger, an increase in cAMP could indiscriminately lead to activation of all ionotropic and metabotropic glutamate receptor subtypes. The central role of extracellular aspartate release in this pathway also raises the interesting possibility of a paracrine signaling mechanism in which an increase in cAMP in one neuron may selectively signal to unstimulated neighboring neurons via aspartate by activation of NMDARs in the target cells.

DA or cAMP regulation of neuronal development mediated by NMDAR activation

DA, cAMP and NMDARs have separately been implicated in the development of synapses and neuronal circuits (Schmidt et al., 1998;
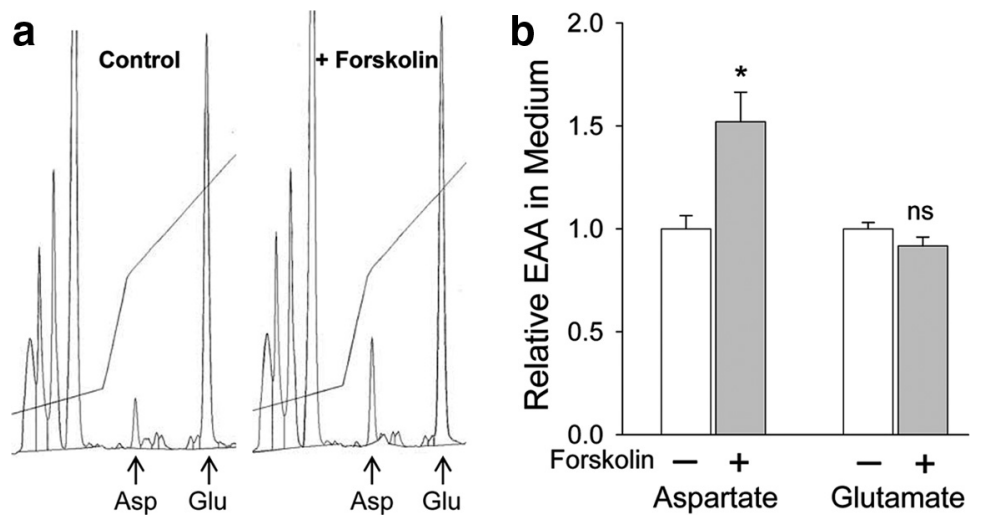

Figure 9. cAMP induces aspartate release from cortical neurons. Four hours after medium replacement, cultures were treated with $100 \mu \mathrm{m}$ forskolin or vehicle (DMSO) for $30 \mathrm{~min}$. Then, $250 \mu$ l of the combined medium from duplicate cultures was removed and subjected to analysis by HPLC as described in Materials and Methods. $\boldsymbol{a}$, Chromatograms showing aspartate and glutamate peaks; forskolin induced an increase in medium aspartate without significantly affecting glutamate. $\boldsymbol{b}$, Summary of measurements from 10 pairs of cultures. Bars show means $\pm \mathrm{SEM}$; ${ }^{*}$ significantly different from control, $p<0.05$ by two-tailed $t$ test; ns, not significantly different from control.

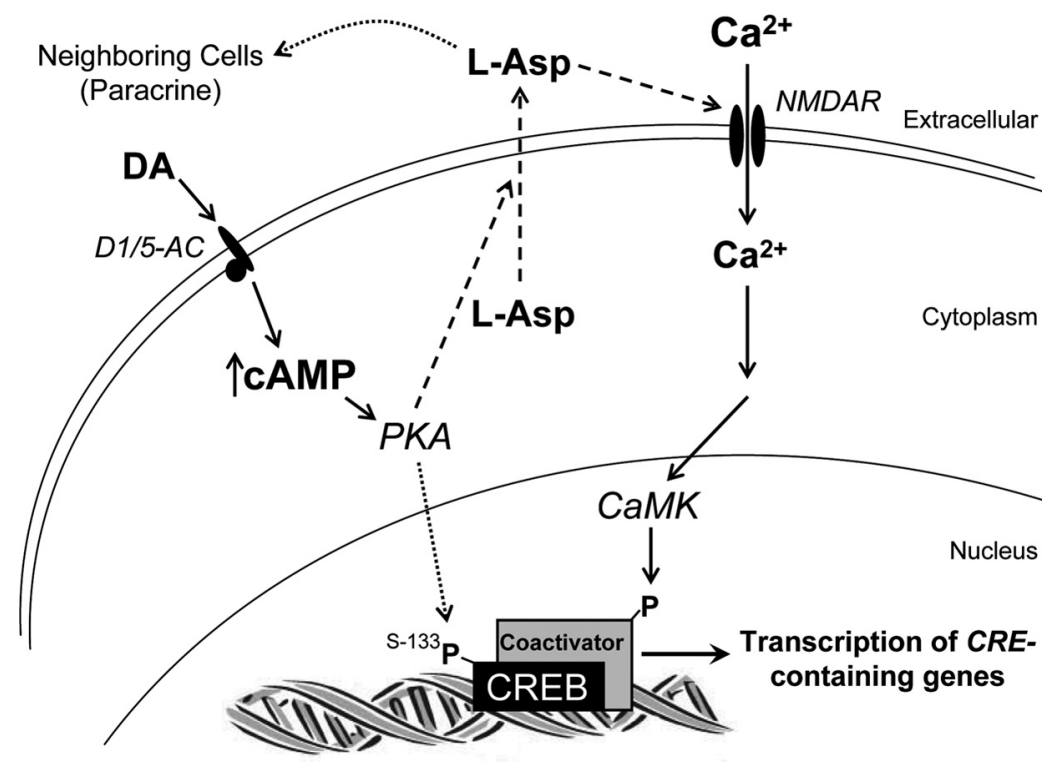

Figure 10. Model illustrating the signaling pathways mediating stimulation of CREB-dependent gene transcription by DA and CAMP in mouse cortical neurons prior to synaptogenesis. Like forskolin, activation of the D1/D5 class of DA receptors (D1/5-AC), which are positively linked to adenylyl cyclase, induces a rise in intracellular CAMP, leading to release of L-aspartate (left, dashed arrows). This CAMP can also stimulate (REB phosphorylation via PKA activation (dotted arrow), but CREB-dependent gene transcription requires activation of ifenprodil-sensitive, NR2B-containing NMDA receptors by aspartate and $\mathrm{Ca}^{2+}$ entry (right, solid arrows). Direct activation of NMDARs by NMDA may induce transcription independently of CAMP, because the NMDA-induced rise in $\mathrm{Ca}^{2+}$ is sufficient to activate both CREB and a coactivator (e.g., (BP) via a CaMK. This schema shows aspartate acting via an autocrine mechanism (i.e., aspartate acts on the same cell that releases it); however, our data are also consistent with a paracrine mechanism (if the released aspartate acts on neighboring neurons)

Gomperts et al., 2000; Cai et al., 2001; Shi et al., 2001; Tominaga-Yoshino et al., 2002; Ji et al., 2005; Ultanir et al., 2007; Adesnik et al., 2008). The autocrine signaling mechanism described in this report, in which the regulation of CREB-dependent gene transcription by cAMP is mediated by aspartate activation of NMDARs, may function in developing neural networks to enable cAMP to modulate synaptogenesis and growth of dendrites and axons before the formation of functional synapses. It will also be important to determine the extent to which this mechanism persists in the adult nervous system and contributes to the modulation of synaptic plasticity and cognitive function by DA and cAMP. 


\section{DA- or cAMP-induced plasticity mediated by NMDAR activation}

Many studies have reported that DA or cAMP signaling promotes protein synthesis-dependent LTP and enhances cognitive function in the mature brain (Frey et al., 1993; Tong et al., 1996; Nguyen and Kandel, 1996; Goldman-Rakic et al., 2000; Nguyen and Woo, 2003; Nie et al., 2007; Isiegas et al., 2008); however, the intracellular signaling cascades that mediate the modulation of synaptic plasticity by cAMP are not well understood. The results reported in this communication suggest that at least some effects of DA and/or cAMP on synaptic plasticity may be mediated by the cAMP/aspartate/NMDAR signaling pathway. Indeed, several reports have described CAMP- or DA-induced changes in plasticity that were blocked by NMDAR antagonists, raising the possibility that the effects of cAMP are mediated by the signaling pathway described here. Otmakhov et al. (2004) reported that the induction of "chemical LTP" by cAMP in hippocampal CA1 pyramidal neurons is mediated by activation of NMDARs. Argilli et al. (2008) found that cocaine-induced plasticity in the ventral tegmental area, which is mediated by activation of AC-coupled D5 DA receptors, requires protein synthesis and is prevented by NMDAR antagonists. Zhang et al. (2009) recently reported that D1/D5 receptor activation modulates spike-timing-dependent plasticity in hippocampal neurons via an NMDAR-dependent pathway. The aspartate+glutamate scavenging system (Fig. 8b) may be useful for determining whether the cAMP/aspartate/ NMDAR pathway described here contributes to these DA-, cAMP-, and NMDAR-dependent forms of synaptic plasticity.

\section{References}

Adesnik H, Li G, During MJ, Pleasure SJ, Nicoll RA (2008) NMDA receptors inhibit synapse unsilencing during brain development. Proc Natl Acad Sci U S A 105:5597-5602.

Argilli E, Sibley DR, Malenka RC, England PM, Bonci A (2008) Mechanism and time course of cocaine-induced long-term potentiation in the ventral tegmental area. J Neurosci 28:9092-9100.

Arias J, Alberts AS, Brindle P, Claret FX, Smeal T, Karin M, Feramisco J, Montminy M (1994) Activation of cAMP and mitogen responsive genes relies on a common nuclear factor. Nature 370:226-229.

Augustine GJ, Santamaria F, Tanaka K (2003) Local calcium signaling in neurons. Neuron 40:331-346.

Bach ME, Barad M, Son H, Zhuo M, Lu YF, Shih R, Mansuy I, Hawkins RD, Kandel ER (1999) Age-related defects in spatial memory are correlated with defects in the late phase of hippocampal long-term potentiation in vitro and are attenuated by drugs that enhance the cAMP signaling pathway. Proc Natl Acad Sci U S A 96:5280-5285.

Barco A, Alarcon JM, Kandel ER (2002) Expression of constitutively active CREB protein facilitates the late phase of long-term potentiation by enhancing synaptic capture. Cell 108:689-703.

Boulanger L, Poo MM (1999) Gating of BDNF-induced synaptic potentiation by cAMP. Science 284:1982-1984.

Bradford SE, Nadler JV (2004) Aspartate release from rat hippocampal synaptosomes. Neuroscience 128:751-765.

Brindle P, Nakajima T, Montminy M (1995) Multiple protein kinase A-regulated events are required for transcriptional induction by cAMP. Proc Natl Acad Sci U S A 92:10521-10525.

Cai D, Qiu J, Cao Z, McAtee M, Bregman BS, Filbin MT (2001) Neuronal Cyclic AMP controls the developmental loss in ability of axons to regenerate. J Neurosci 21:4731-4739.

Cardinaux JR, Notis JC, Zhang Q, Vo N, Craig JC, Fass DM, Brennan RG, Goodman RH (2000) Recruitment of CREB binding protein is sufficient for CREB-mediated gene activation. Mol Cell Biol 20:1546-1552.

Carlezon WA Jr, Duman RS, Nestler EJ (2005) The many faces of CREB. Trends Neurosci 28:436-445.

Chavez-Noriega LE, Stevens CF (1994) Increased transmitter release at excitatory synapses produced by direct activation of adenylate cyclase in rat hippocampal slices. J Neurosci 14:310-317.

Conkright MD, Guzmán E, Flechner L, Su AI, Hogenesch JB, Montminy M
(2003) Genome-wide analysis of CREB target genes reveals a core promoter requirement for cAMP responsiveness. Mol Cell 11:1101-1108.

Curras MC, Dingledine R (1992) Selectivity of amino acid transmitters acting at $\mathrm{N}$-methyl-D-aspartate and amino-3-hydroxy-5-methyl-4-isoxazoleproprionate receptors. Mol Pharmacol 41:520-526.

Dash PK, Karl KA, Colicos MA, Prywes R, Kandel ER (1991) cAMP response element-binding protein is activated by $\mathrm{Ca}^{2+} /$ calmodulin- as well as cAMP-dependent protein kinase. Proc Natl Acad Sci U S A 88: 5061-5065.

Deisseroth K, Bito H, Tsien RW (1996) Signaling from synapse to nucleus: postsynaptic CREB phosphorylation during multiple forms of hippocampal synaptic plasticity. Neuron 16:89-101.

Dudman JT, Eaton ME, Rajadhyaksha A, Macías W, Taher M, Barczak A, Kameyama K, Huganir R, Konradi C (2003) Dopamine D1 receptors mediate CREB phosphorylation via phosphorylation of the NMDA receptor at Ser897-NR1. J Neurochem 87:922-934.

Fleck MW, Henze DA, Barrionuevo G, Palmer AM (1993) Aspartate and glutamate mediate excitatory synaptic transmission in area CA1 of the hippocampus. J Neurosci 13:3944-3955.

Frauli M, Neuville P, Vol C, Pin J-P, Prezeau L (2006) Among the twenty classical L-amino acids, only glutamate directly activates metabotropic glutamate receptors. Neuropharmacol 50:245-253.

Frey U, Huang YY, Kandel ER (1993) Effects of cAMP simulate a late stage of LTP in hippocampal CA1 neurons. Science 260:1661-1664.

Goldman-Rakic PS, Muly EC 3rd, Williams GV (2000) $D_{1}$ receptors in prefrontal cells and circuits. Brain Res Rev 31:295-301.

Gomperts SN, Carroll R, Malenka RC, Nicoll RA (2000) Distinct roles for ionotropic and metabotropic glutamate receptors in the maturation of excitatory synapses. J Neurosci 20:2229-2237.

Gonzalez GA, Montminy MR (1989) Cyclic AMP stimulates somatostatin gene transcription by phosphorylation of CREB at serine 133. Cell 59: 675-680.

Han EB, Stevens CF (2009) Development regulates a switch between postand presynaptic strengthening in response to activity deprivation. Proc Natl Acad Sci U S A 106:10817-10822.

Hardingham GE, Bading H (2002) Coupling of extrasynaptic NMDA receptors to a CREB shut-off pathway is developmentally regulated. Biochim Biophys Acta 1600:148-153.

Hardingham GE, Chawla S, Cruzalegui FH, Bading H (1999) Control of recruitment and transcription-activating function of CBP determines gene regulation by NMDA receptors and L-type calcium channels. Neuron 22:789-798.

Hardingham GE, Arnold FJ, Bading H (2001) A calcium microdomain near NMDA receptors: on switch for ERK-dependent synapse-to-nucleus communication. Nat Neurosci 4:565-566.

Hardingham GE, Fukunaga Y, Bading H (2002) Extrasynaptic NMDARs oppose synaptic NMDARs by triggering CREB shut-off and cell death pathways. Nat Neurosci 5:405-414.

Huang YY, Kandel ER (1995) D1/D5 receptor agonists induce a protein synthesis-dependent late potentiation in the CA1 region of the hippocampus. Proc Natl Acad Sci U S A 92:2446-2450.

Huang YY, Simpson E, Kellendonk C, Kandel ER (2004) Genetic evidence for the bidirectional modulation of synaptic plasticity in the prefrontal cortex by D1 receptors. Proc Natl Acad Sci U S A 101:3236-3241.

Impey S, Fong AL, Wang Y, Cardinaux JR, Fass DM, Obrietan K, Wayman GA, Storm DR, Soderling TR, Goodman RH (2002) Phosphorylation of CBP mediates transcriptional activation by neural activity and CaM kinase IV. Neuron 34:235-244.

Impey S, McCorkle SR, Cha-Molstad H, Dwyer JM, Yochum GS, Boss JM, McWeeney S, Dunn JJ, Mandel G, Goodman RH (2004) Defining the CREB regulon: a genome-wide analysis of transcription factor regulatory regions. Cell 119:1041-1054.

Isiegas C, McDonough C, Huang T, Havekes R, Fabian S, Wu LJ, Xu H, Zhao MG, Kim JI, Lee YS, Lee, HR, Ko HG, Lee N, Choi SL, Lee JS, Son H, Zhuo M, Kaang BK, Abel T (2008) A novel conditional genetic system reveals that increasing neuronal cAMP enhances memory and retrieval. J Neurosci 28:6220-6230.

Ji Y, Pang PT, Feng L, Lu B (2005) Cyclic AMP controls BDNF-induced TrkB phosphorylation and dendritic spine formation in mature hippocampal neurons. Nat Neurosci 8:164-172.

Johnson KB, Criswell HE, Jensen KF, Simson PE, Mueller RA, Breese GR (1992) Comparison of the D1-dopamine agonists SKF-38393 and 
A-68930 in neonatal 6-hydroxydopamine-lesionsed rats: behavioral effects and induction of $c$-fos-like immunoreactivity. J Pharmacol Exp Ther 262:855-865.

Jones LB, Stanwood GD, Reinoso BS, Washington RA, Wang HY, Friedman E, Levitt P (2000) In utero cocaine-induced dysfunction of dopamine D1 receptor signaling and abnormal differentiation of cerebral cortical neurons. J Neurosci 20:4606-4614.

Kao HT, Song HJ, Porton B, Ming GL, Hoh J, Abraham M, Czernik AJ, Pieribone VA, Poo MM, Greengard P (2002) A protein kinase A-dependent molecular switch in synapsins regulates neurite outgrowth. Nat Neurosci 5:431-437.

Kingsbury TJ, Murray PD, Bambrick LL, Krueger BK (2003) $\mathrm{Ca}^{2+}$ dependent regulation of TrkB expression in neurons. J Biol Chem 278:40744-40748.

Konradi C, Macías W, Dudman JT, Carlson RR (2003) Striatal proenkephalin gene induction: coordinated regulation by cyclic AMP and calcium pathways. Mol Brain Res 115:157-161.

Lonze BE, Ginty DD (2002) Function and regulation of CREB family transcription factors in the nervous system. Neuron 35:605-623.

Lu Y, Li Y, Herin GA, Aizenman E, Epstein PM, Rosenberg PA (2004) Elevation of intracellular cAMP evokes activity-dependent release of adenosine in cultured rat forebrain neurons. Eur J Neurosci 19:2669-2681.

Ma L, Zablow L, Kandel ER, Siegelbaum SA (1999) Cyclic AMP induces functional presynaptic boutons in hippocampal CA3-CA1 neuronal cultures. Nat Neurosci 2:24-30.

Matthews CC, Zielke HR, Parks DA, Fishman PS (2003) Glutamatepyruvate transaminase protects against glutamate toxicity in hippocampal slices. Brain Res 978:59-64.

Matthews RP, Guthrie CR, Wailes LM, Zhao X, Means AR, McKnight GS (1994) Calcium/Calmodulin-dependent protein kinase types II and IV differentially regulate CREB-dependent gene expression. Mol Cell Biol 14:6107-6116.

Mayr B, Montminy M (2001) Transcriptional regulation by the phosphorylation dependent factor CREB. Nat Rev Mol Cell Biol 2:599-609.

Naraghi M, Neher E (1997) Linearized buffered $\mathrm{Ca}^{2+}$ diffusion in microdomains and its implications for calculation of $\left[\mathrm{Ca}^{2+}\right]$ at the mouth of a calcium channel. J Neurosci 17:6961-6973.

Navedo MF, Amberg GC, Votaw VS, Santana LF (2005) Constitutively active L-type $\mathrm{Ca}^{2+}$ channels. Proc Natl Acad Sci U S A 102:11112-11117.

Nguyen PV, Kandel ER (1996) A macromolecular synthesis-dependent late phase of long-term potentiation requiring cAMP in the medial perforant pathway of rat hippocampal slices. J Neurosci 16:3189-3198.

Nguyen PV, Woo NH (2003) Regulation of hippocampal synaptic plasticity by cyclic AMP-dependent protein kinases. Prog Neurobiol 71:401-437.

Nie T, McDonough CB, Huang T, Nguyen PV, Abel T (2007) Genetic disruption of protein kinase $\mathrm{A}$ anchoring reveals a role for compartmentalized kinase signaling in theta-burst long-term potentiation and spatial memory. J Neurosci 27:10278-10288.

O’Brien RJ, Fischbach GD (1986) Modulation of embryonic chick motoneuron glutamate sensitivity by interneurons and agonists. J Neurosci 6:3290-3296.

Otmakhov N, Khibnik L, Otmakhova N, Carpenter S, Riahi S, Asrican B, Lisman J (2004) Forskolin-induced LTP in the CA1 hippocampal region is NMDA receptor dependent. J Neurophysiol 91:1955-1962.

Otmakhova NA, Lisman JE (1998) D1/D5 dopamine receptors inhibit depotentiation at CA1 synapses via cAMP-dependent mechanism. J Neurosci 18:1270-1279.

Parpura V, Haydon PG (2000) Physiological astrocytic calcium levels stimulate glutamate release to modulate adjacent neurons. Proc Natl Acad Sci U S A 97:8629-8634.

Pfaffl MW (2001) A new mathematical model for relative quantification in real-time RT-PCR. Nucleic Acids Res 29:e45.
Rajadhyaksha A, Barczak A, Macías W, Leveque JC, Lewis SE, Konradi C (1999) L-type $\mathrm{Ca}^{2+}$ channels are essential for glutamate-mediated CREB phosphorylation and $c$-fos gene expression in striatal neurons. J Neurosci 19:6348-6359.

Rutledge EM, Kimelberg HK (1996) Release of $\left[{ }^{3} \mathrm{H}\right]$-D-aspartate from primary astrocyte cultures in response to raised external potassium. J Neurosci 16:7803-7811.

Schmidt U, Pilgrim C, Beyer C (1998) Differentiative effects of dopamine on striatal neurons involve stimulation of the cAMP/PKA pathway. Mol Cell Neurosci 11:9-18.

Seino S, Shibasaki T (2005) PKA-dependent and PKA-independent pathways for cAMP-regulated exocytosis. Physiol Rev 85:1303-1342.

Shen W, Flajolet M, Greengard P, Surmeier DJ (2008) Dichotomous dopaminergic control of striatal synaptic plasticity. Science 321:848-851.

Sheng M, Thompson MA, Greenberg ME (1991) CREB: a $\mathrm{Ca}^{2+}$-regulated transcription factor phosphorylated by calmodulin-dependent kinases. Science 252:1427-1430.

Shi J, Aamodt SM, Townsend M, Constantine-Paton M (2001) Developmental depression of glutamate neurotransmissin by chronic low-level activation of NMDA receptors. J Neurosci 21:6233-6244.

Skeberdis VA, Chevaleyre V, Lau CG, Goldberg JH, Pettit DL, Suadicani SO, Lin Y, Bennett MV, Yuste R, Castillo PE, Zukin RS (2006) Protein kinase A regulates calcium permeability of NMDA receptors. Nat Neurosci 9:501-510.

Tabuchi A, Sakaya H, Kisukeda T, Fushiki H, Tsuda M (2002) Involvement of an upstream stimulatory factor as well as cAMP-responsive elementbinding protein in the activation of brain-derived neurotrophic factor gene promoter I. J Biol Chem 277:35920-35931.

Tominaga-Yoshino K, Kondo S, Tamotsu S, Ogura A (2002) Repetitive activation of protein kinase $\mathrm{A}$ induces slow and persistent potentiation associated with synaptogenesis in cultured hippocampus. Neurosci Res 44:357-367.

Tong G, Malenka RC, Nicoll RA (1996) Long-term potentiation in cultures of single hippocampal granule cells: a presynaptic form of plasticity. Neuron 16:1147-1157.

Trudeau LE, Emery DG, Haydon PG (1996) Direct modulation of the secretory machinery underlies PKA-dependent synaptic facilitation in hippocampal neurons. Neuron 17:789-797.

Ultanir SK, Kim JE, Hall BJ, Deerinck T, Ellisman M, Ghosh A (2007) Regulation of spine morphology and spine density by NMDA receptor signaling in vivo. Proc Natl Acad Sci U S A 104:19553-19558.

Vo N, Goodman RH (2001) CREB-binding protein and p300 in transcriptional regulation. J Biol Chem 276:13505-13508.

West AE, Griffith EC, Greenberg ME (2002) Regulation of transcription factors by neuronal activity. Nat Rev Neurosci 3:921-931.

Woodhall GL, Ayman G, Jones RSG (2007) Differential control of two forms of glutamate release by group III metabotropic glutamate receptors at rat entorhinal synapses. Neuroscience 148:7-21.

Wozny C, Maier N, Fidzinski P, Breustedt J, Behr J, Schmitz D (2008) Differential cAMP signaling at hippocampal output synapses. J Neurosci 28:14358-14362.

Xia Z, Dudek H, Miranti CK, Greenberg ME (1996) Calcium influx via the NMDA receptor induces immediate early gene transcription by a MAP kinase/ERK-dependent mechanism. J Neurosci 16:5425-5436.

Xu W, Kasper LH, Lerach S, Jeevan T, Brindle PK (2007) Individual CREBtarget genes dictate usage of distinct cAMP-responsive coactivation mechanisms. EMBO J 26:2890-2903.

Yuan SH, Qiu Z, Ghosh A (2009) TOX3 regulates calcium-dependent transcription in neurons. Proc Natl Acad Sci U S A 106:2909-2914.

Zhang JC, Lau P, Bi G (2009) Gain in sensitivity and loss in temporal contrast of STDP by dopaminergic modulation at hippocampal synapses. Proc Natl Acad Sci U S A 106:13028-13033. 